\title{
Effective Communication As a Tool for Achieving Organizational Goals
}

Mohamad Idham Hj. Md Razak, Wan Azfarozza Wan Athmar, Noorazura
Durani, Asraf Johar Salleh, and Nuralifah Ilyana Binti Hamdan UiTM Melaka, Malaysia

\section{Abstract}

Communication is a key element of human behaviour. In other words, it is an act by which one person gives to or receives information from other person about that person's needs, desire, knowledge, opinions and perceptions. Communication in the workplace can occur under many different modes such as writing, verbal and nonverbal (body gestures and facial expression). In business and industry, communication helps to align workers to work with one another and to achieve the objective of the organization, which means objectives, can be in the target, attained and improved. Without workplace communication, nothing can be done.

Mohamad Idham Hj. Md Razak iedham@melaka.uitm.edu.my Keywords: communication, organization, workplace

Received: 18 January 2019

Accepted: 24 March 2019

Published: 31 March 2019

Publishing services provided by Knowledge E

\section{Introduction}

(c) Mohamad Idham Hj. Md Razak et al. This article is distributed under the terms of the

Communication is a key element of human behavior. People use communication to interact, socialize, share feeling, provide information, express emotion, giving opinion etc. In other words, communication is an act by which one person known as sender gives information to someone else known as receiver based on person's needs, desire, knowledge, opinions and perceptions. Keyton's study (as cited in [1]) found that communication can be defined as procedure of transmitting information from one person to another person and understand it. Communication also known as the essence of social relation by helping people to understand themselves, to keep in touch with people, to understand and predict their response to a situation.

Effective communication allows the sender to understand the emotion and intention of sending the information to the receiver. Unable to deliver a clearly message and makes the receiver understood is one of the problems that we are facing today in the organization [2]. We do have talented employee in the organization but how to make S OPEN ACCESS them stay longer is a big question. We normally heard that several reasons employees 
leaving the organization because of getting offer on higher pay, the new company gives more benefits, easy to build career development and so on.

Effective communication among employees in the organization are relate on the mode of communication to develop an understanding of strategies that foster quality communication which gives impact to any organization success. According to [3] employers and employees must be consistent, clear, complete and accurate when communicate between each other. Some of the barriers may include body gesture, language, cultural, emotions and different personalities [4] when communication breakdowns occur.

\section{Literature Review}

Reaching organizational goals and objectives have always been a challenge. There are many ways of meeting these goals and communication plays an integral part in doing so. Through organizational communication, the stimulation and motivation of employees could be achieved [5]. Communication consists of verbal and non-verbal. As important as verbal, non-verbal communication could also ensure a successful workplace environment. These communications include gestures, posture and facial expression [6]. Nonverbal communication is also a way a person expresses their feelings and emotions. 65 percent to 75 percent of communication is nonverbal. Our sense and thoughts about others are part of nonverbal communication [7]. As we communicate with each other, a breakdown in the communication can be inevitable as we misinterpreted the information we received. This could happen due to the improper word choice, differing communication style and individual's perspectives [8].

In the context of communication climate, it can be defined as internal environment of information exchange between employees in an organization whether through formal or informal networks. Information flows freely when the communication climate is open and when the information flow is closed it can create a negative workplace environment [9]. This closed information flow exists when an individual in an organization give their contribution however is not being appreciated. This leads to difficulties for the employees to get and give information and to take action which often resulting in the feeling of being uncomfortable and unwilling to interact with each other [10].

The role of a supervisor is also important in ensuring a positive workplace environment. Supervisor can be defined as a person in front line management who monitors employee's performance based on task given. Part of the supervisor's roles are hiring, disciplining, promoting, punishing, rewarding and any employment activities in the workplace [11]. 
When it comes to communication supervisor needs to communicate effectively in terms of transferring knowledge and motivation. Not just giving orders and directions, listening skills are perceived as a crucial part in the supervisory communications [12]. Sullivan's Motivating Language Theory (MLT) hypothesizes that employee's performance and job satisfaction would be impacted positively when the superior uses motivating language, giving direction, sharing feelings and explaining the organization's culture. This theory also proved that strategic applications of leader oral communication have positive measurable effects on employee's performance and job satisfaction [13-15].

The communication component in an organization plays a vital role in achieving organization's objectives. Globalization, deregulation of markets, the everchanging of customer demands and increasing competition meant that each organization must be able to manage adversities within the organization [16]. Effective communication is one of them.

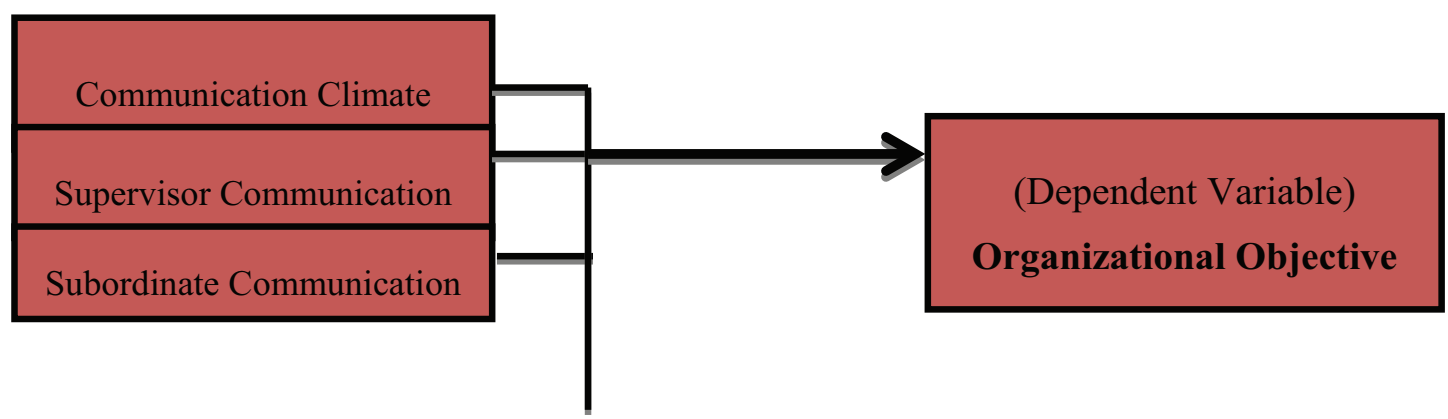

Figure 1: Shows the theoretical framework for dimension of communication satisfaction by [17]. Framework of dimension of communication satisfaction.

\section{Research Methodology}

The research strategy that was being used by the researchers to collect the data was a survey research. A survey is a system for collecting information from or about people to describe, compare or explain their knowledge, attitudes and behavior [18]. Under this survey, the researchers used questionnaires to draw out the views from a large group of employees in the organization Pejabat Setiausaha Kerajaan Negeri Sembilan (PSUKNS). This overview of survey and questionnaires clarified the place of questionnaires as a data collection tool in quantitative research design. The questions in survey instruments are typically arranged into self-administered questionnaires that respondents complete on his or her paper that will be distributed. The population of this research were 193 employees that came from different units of Pejabat Setiausaha Kerajaan Negeri Sembilan (PSUKNS). 
However, the samples used for this research were 130 employees from different units at PSUKNS. A carefully selected sample can provide data representative of the population from which it is drawn. In this research, the sampling frame was employees because the researchers wanted to measure the effective communication for achieving organizational objective in PSUKNS. In this research, the total number of the employees were listed about 155 which questionnaires were distributed to Unit Perancang Ekonomi Negara (UPEN), Badan Kawal Selia Air (BKSA), Unit Dewan Undangan Negeri (UDUN), Bahagian Pengurusan Sumber Manusia (BPSM), Pejabat Menteri Besar, Unit Perumahan, Bahagian Khidmat Pengurusan (BKP), Unit Kerajaan Tempatan (UKT), Unit Korporat, Inovasi dan Kualiti (UKIK) and Unit Perumahan.

\section{Results and Finding}

Based on the Table 1 shows that there is a positive relationship between communication climate and organizational objective with the Pearson correlation value is 0.470 , which indicates that there is a strong correlation between the independent and dependent variable and the significant value is 0.000 which less than 0.05 . Secondly, there is a positive relationship between supervisor communication and organizational objective which the Pearson correlation value is 0.590 that indicates strong correlation between the independent and dependent variable which the significant value also 0.000 which less than 0.05 . Thirdly, there is a positive relationship between subordinate communication and organizational objective with the Pearson correlation value is 0.434 which means there is strong correlation between independent and dependent variable and significant value is 0.000 which less than 0.05 .

In this study shows that all independent variables, which are communication climate, supervisor communication and subordinate communication, have significant correlation with organizational objective.

Furthermore, based on the Table 2, the $F$-value 33.820 and significant value is 0.000 which means the model is fit and acceptable and result can be used for hypothesis. Next is $\mathrm{R}$ square value. It is important because result will show the percentage of influence of the independent variable effect the dependent variable. For the $R^{2}$ is 0.452 means 45.2 percent of variance in organizational objective (dependent variable) explain by variation in communication climate, supervisor communication and subordinate communication (independent variables). Hence, 54.8 percent can be explained by other factor which is not included in this study. For the standardized coefficient (Beta) value of communication climate is positive impact of 0.299 and significant value is 0.000 which is less than 0.05 . 
TABLE 1: Correlation between communication climate, supervisor communication and subordinate communication for achieving organizational objective.

\begin{tabular}{|c|c|c|c|c|c|}
\hline & & TCC & TSP & TSB & TOO \\
\hline \multirow{3}{*}{$\begin{array}{l}\text { Total communication } \\
\text { climate }\end{array}$} & Pearson Correlation & 1 & & & \\
\hline & Sig. (2-tailed) & & & & \\
\hline & $\mathrm{N}$ & 127 & & & \\
\hline \multirow{3}{*}{$\begin{array}{l}\text { Total supervisor } \\
\text { communication }\end{array}$} & Pearson Correlation & $.395^{* *}$ & 1 & & \\
\hline & Sig. (2-tailed) & 0 & & & \\
\hline & $N$ & 127 & 127 & & \\
\hline \multirow{3}{*}{$\begin{array}{l}\text { Total subordinate } \\
\text { communication }\end{array}$} & Pearson Correlation & $.123^{* *}$ & 0.482 & 1 & \\
\hline & Sig. (2-tailed) & 0.169 & 0 & & \\
\hline & $\mathrm{N}$ & 127 & 127 & 127 & \\
\hline \multirow{3}{*}{$\begin{array}{l}\text { Total organizational } \\
\text { objective }\end{array}$} & Pearson Correlation & $.470^{* *}$ & $.590^{* *}$ & $.434^{* *}$ & 1 \\
\hline & Sig. (2-tailed) & 0 & 0 & 0 & \\
\hline & $\mathrm{N}$ & 127 & 127 & 127 & 127 \\
\hline
\end{tabular}

So, this independent variable influence to organizational objective. Secondly, Beta-value of supervisor communication is positive impact of 0.365 and significant value is 0.000 that less than 0.05, so it is influence the organizational objective. Lastly, Beta-value for subordinate communication is also positive impact of 0.221 and significance value is 0.005 which less than 0.05 and this influence to organizational objective.

In this study, all variables which communication climate are, supervisor communication and subordinate communication are significant because less than $p$-value 0.05 . But the highest influence for achieving organizational objective in PSKNS is supervisor communication because it has highest Beta- value, which is 0.365 .

\section{Conclusion}

Based on the data findings, its shows that all independent variables, which are communication climate, supervisor communication and subordinate communication, are influential in achieving organizational objective among employees in PSKNS. All these variables are relating to effective communication that need to be developed in the workplace in order to achieve organizational objective and at the same time can meet the vision and 
TABLE 2: Anova, model summary and coefficient.

\begin{tabular}{|c|c|c|c|c|c|c|}
\hline \multicolumn{7}{|c|}{ ANOVA $^{a}$} \\
\hline & Model & $\begin{array}{l}\text { Sum of } \\
\text { Squares }\end{array}$ & df & $\begin{array}{l}\text { Mean } \\
\text { Square }\end{array}$ & $F$ & Sig. \\
\hline \multirow[t]{3}{*}{1} & Regression & 15.384 & 3 & 5.128 & 33.820 & $.000^{b}$ \\
\hline & Residual & 18.649 & 123 & .152 & & \\
\hline & Total & 34.033 & 126 & & & \\
\hline
\end{tabular}

\begin{tabular}{|l|c|c|c|c|}
\hline \multicolumn{5}{|c|}{ Model Summary } \\
\hline Model & $\mathrm{R}$ & $\mathrm{R}$ Square & $\begin{array}{c}\text { Adjusted R } \\
\text { Square }\end{array}$ & $\begin{array}{c}\text { Std. Error of } \\
\text { the Estimate }\end{array}$ \\
\hline 1 & $.672^{a}$ & .452 & .439 & .38938 \\
\hline
\end{tabular}

\begin{tabular}{l|c|c|c|c|c|}
\hline \multicolumn{5}{|c|}{ Coefficients $^{a}$} \\
Model & \multicolumn{2}{c|}{ Unstandardized Coefficients } & $\begin{array}{c}\text { Standardized } \\
\text { Coefficients }\end{array}$ & $\mathrm{t}$ & Sig. \\
\hline & $\mathrm{B}$ & Std. Error & Beta & \\
\hline (Constant) & .552 & .312 & & 1.770 & .079 \\
\hline TOTAL COMMUNICATION & .264 & .064 & .299 & 4.096 & .000 \\
\hline TOTAL SUPERVISOR & .379 & .086 & .365 & 4.423 & .000 \\
\hline TOTAL SUBORDINATE & .224 & .078 & .221 & 2.893 & .005 \\
\hline Dependent Variable: TOTAL ORGANIZATIONAL Significant $P$-value is $<0.05$ & \\
\hline
\end{tabular}

mission of the organization. As for recommendation for future research, a similar study should be conducted in terms of effective communication for achieving organizational objective in private sectors. This is to determine whether there is any difference of effective communication between a government and a private sector.

\section{Acknowledgement}

First of all we would like to thank God Almighty for giving us the knowledge, ability and opportunity to undertake this research study. We would also like to express our utmost gratitude and appreciation to Pejabat Setiausaha Kerajaan Negeri Sembilan (PSUKNS) and also its' employees from Unit Perancang Ekonomi Negara (UPEN), Badan Kawal Selia Air (BKSA), Unit Dewan Undangan Negeri (UDUN), Bahagian Pengurusan Sumber Manusia (BPSM), Pejabat Menteri Besar, Unit Perumahan, Bahagian Khidmat Pengurusan (BKP), Unit Kerajaan Tempatan (UKT), Unit Korporat, Inovasi dan Kualiti (UKIK) and Unit Perumahan who have given us their time and full cooperation over the course of 
this research. Finally, we would like to thank our families and friends who have always been there to support us in our endeavors.

\section{References}

[1] Lunenburg, F.C. (2010). Communication: The process, barriers, and improving effectiveness. Schooling, Volume 1, Number 1, pp. 1- 11.

[2] Helpguide.org official website. (2018). Retrieved from https://www.helpguide.org/ articles/relationships-communication/effectivecommunication.htm

[3] Chiang, C-F. Jang, S-C. Canter, D. \& Prince, B. (2008). An expectancy model for hotel employee motivation: Examining the Moderating Role of Communication Satisfaction. International Journal of Hospitality \& Tourism Administration, 9, 4, 327351.

[4] Feigenbaum, E. (2012). About barriers to effective communication within the workplace. Retrieved from: http://smallbusiness.chron.com/barriers-effectivecommunication-within-workplace-3185.html

[5] Clampitt, P.G. \& Downs. C.W. (1993). Employee Perceptions of the Relationship between Communication and Productivity: A Field Study. The Journal of Business Communication, 30(1), 5-28.

[6] Burgoon, J. K, Guerrero, L. K \& Manusov, V. (2011). Nonverbal signals. In M. L. Knapp \& J. Daly (Eds.) Handbook of interpersonal communication: 239-280. Thousand Oaks, CA: Sage.

[7] Schwartz, L.C. (2012). Nonverbal Communication with Workplace Interactions. Retrieved from: http://smallbusiness.chron.com/nonverbal-communicationworkplace-interactions-

[8] Hanes, T. (2010). What is verbal communication? Retrieved from: www.livestrong. com/article/150573-what-is-verbal-communication/.

[9] William, J. (2001). Open communication climate. Retrieved from: https://www.pdx. edu/sites/www.pdx.edu.cae/files/Workplace.pdf

[10] Brian. (2011). Creating an Effective Communication Climate. Dr.Brian's Smarta Marketing Blog Number 1. Retrieved from: https://smartamarketing.wordpress.com/ 2011/01/22/creating-an-effective-communication-climate/

[11] Richason, O. (2012). What is effective workplace communication? Retrieved from: http://smallbusiness.chron.com/effective-workplace-communication-822.html

[12] Kim, S. (2002). Participative Management and Job Satisfaction: Lesson form Management Leadership. Public Administration Review, Vol. 62, No. 2, pp. 231-241. 
[13] Mayfield M., Mayfield J., \& Kopf J. (1998). The effects of Leader Motivating Language on Subordinate Performance and Satisfaction. Human Resource Management. Vol. 37, No. 3,4, pp. 235-248.

[14] Mayfield M., \& Mayfield, J. (2006). The Benefits of Leader Communication on Parttime Worker Outcomes: A Comparison between Part-time and Full-time Employees Using Motivating Language. The Journal of Business Strategies, Vol. 23, No. 2, pp. 131-153.

[15] Mayfield, M., \& Mayfield, J. (2009). The Role of Leader-Follower Relationship in Leader Communication: The Test Using the LMX and Motivating Language Models. Journal of Business Enquiry, 8 (1), pp 65- 82.

[16] Becker, B. and Gerhart, B. (1996). The impact of human resource management on organizational performance: Progress and Prospects. Academy of Management Journal, 39, 779-802.

[17] Downs, C. W. \& Hazen, M. D. (1977). A factor analytic study of communication satisfaction. The Journal of Business Communication, 14, 64-73.

[18] Fink, A. (2003). The survey handbook: The survey kit Volume 1. (2 ${ }^{\text {nd }}$ edition). Thousand Oaks, Calif: Sage. 